\title{
More on Strikes by Public Employees
}

\section{Harry $\mathrm{H}$. Wellington $\uparrow$ and Ralph K. Winter, Jr. ††}

We have two brief observations on the paper by Messrs. Burton and Krider. ${ }^{1}$ First, we suggest that society is not limited to a choice between their strike and no-strike alternatives. Our earlier article argued that the typical municipal political structure is vulnerable to strikes by well entrenched public employee unions, ${ }^{2}$ and that, given this existing political structure, the no-strike model is preferable to the strike model. We stated, however, that changes in the political structure which reduce the vulnerability of municipal employers to strikes by public employees can be made and that we intended (and we still do intend) to explore these possibilities in a future article. ${ }^{3}$ There is, therefore, a third model -one which permits some strikes in conjunction with various changes in municipal political structures.

Second, we wish to define what seems to be the principal area of our disagreement with Messrs. Burton and Krider. All agree that the services performed by some public employees are in one way or another "essential" and that this "essentiality" is in some sense related to society's ability to tolerate strikes. However, which employees under the Burton-Krider strike model are to have union activities limited depends very much on one's view of essentiality. It is now clear that our vision is different from theirs.

For them, the essentially of the service depends on the extent to which disruption of the service by a strike would "immediately endanger public health and safety." They limit the concept to situations creating an immediate danger to the public health and safety and, therefore, advocate a prohibition on strikes affecting municipal police

$\dagger$ Edward J. Phelps Professor of Law, Yale University.

\pm Professor of Law, Yale University.

1. We cannot excuse by pleading ignorance the jurisprudential lapses we obviously committed in our earlier article. We must confess that we knew Coke and Holmes and Cardozo had spoken of law and its nature. That we ignored the words of these great jurists shows how easy it is to become obsessed with the trivial and the current, and to forget the enduring values that are enshrined in Anglo-American Inw, and the glorious literature it has spawned.

2. Many such unions are poorly organized and poorly led. When that is the case the model suggested in our earlier article is inapplicable. It seems rather plain, however, that the trend is toward better organization and better leadership.

3. The intend there to discuss, for instance, one matter raised by Messrs. Burton and Krider, the subcontracting or shedding of particular government functions.

4. We can all probably also agree that some governmental emplojees do not perform services which are essential in any sense of the word. 
and fire functions. They would permit strikes in other areas, such as education. We agree that strikes which create an immediate dinger to public health and welfare cannot be tolerated, and that any concept of essentiality must, at a minimum, embrace such situations.

We claim more for the concept, however. ${ }^{5}$ Many government services are essential in two additional senses, senses which are of critical importance to the issues before us. First, the demand for numerous gova ernmental services is relatively inelastic; that is, relatively insensitive to changes in price. Indeed, the lack of close substitutes is typical of many governmental endeavors. ${ }^{6}$ And, since at least the time of Marshall's Principles of Economics, the elasticity of demand for the final service or product has been considered a major determinant of union power. ${ }^{7}$ Because the demand for labor is derived from the demand for the product, inelasticity on the product side tends to reduce the employment-benefit trade-off unions face. As our earlier article noted, this is as much the case in the private as in the public sector. But, in the private sector product inelasticity is not typical. Moreover, there is the further restraint on union power created by the real possibility of nonunion entrants into the product market. In the public sector, inelasticity of demand seems to us more the rule than the exception, and nonunion rivals are not generally a serious problem.

Consider education. A strike by teachers may never create an immediate danger to public health and welfare. Nevertheless, teachers rarely need fear unemployment as a result of union-induced wage increases, and the threat of an important non-union rival (competitive private schools) is not to be taken seriously so long as potential consumers of private education must pay taxes to support the public school system.

The third sense in which the concept of essentiality has significance is the extent to which the disruption of a government service inconveniences municipal voters. A teachers' strike may not endanger public health or welfare. It may, however, seriously inconvenience parents and other citizens who, as voters, have the power to punish one of the parties -and always the same party, the political leadership_to the dispute. How can anyone any longer doubt the vulnerability of a municipal employer to this sort of pressure? Was it simply a matter of indifference

5. If one were using "essentiality" in merely a descriptive sense, the Burton-Krider definition might well be satisfactory. They employ this concept, however, as the touclistone for resolving the strike question. When so used, their definition is totally inadcquatc.

6. Sometimes this is so because of the nature of the endeavor, national defense, for example, and sometimes because of the existence of the governmental operation necessarily inhibits entry by private entities, as in the case of elementary colucation.

7. A. Marshall, Principles of Economics 383-86 (8th ed. 1920). 
to Mayor Lindsay in September, 1969, whether another tenchers' strike occurred on the eve of a municipal election? Did the size and the speed of the settlement with the U.F.T. suggest nothing about one first-rate politician's estimate of his vulnerability?

Messrs. Burton and Krider's disagreement with us on this point seems based principally on their conviction that anticipation of increased taxes as the result of a large labor settlement will countervail the felt inconvenience of a strike, and that municipalities are not, therefore, overly vulnerable to strikes by public employees. We remain convinced, however, that governmental budgets are so complex that the effect of any particular labor settlement on the typical municipal budget is a matter of very low visibility. It will not, therefore, significantly deter voters, inconvenienced by a strike, from compelling political leaders to settle quickly. Moreover, as we noted in our earlier article, municipalities are often subsidized by other political entities-the nation or state -and the cost of a strike settlement may not be borne by those demanding an end to the strike. Surely Mayor Lindsay's pleas for federal and state aid because of the increased cost of municipal services are not totally unrelated to his labor problems.

The sum of our position then is-given today's typical municipal structure-that once public employee unions become well established, they will, if they are allowed to strike, have too much power. For the effect of the strike weapon ${ }^{8}$ is to put competing claimants in the political process (at all levels of government) at a disadvantage substantial enough for us to insist that it constitutes, what in our earlier article we called, a "distortion" of the "'normal' American political process." This distortion, moreover, may make everyone from large taxpayers to welfare recipients poorer than they are, and the cities less livable, but more volatile, than they have become.

8. Our convictions remain unshaken in the face of Messrs. Burton and Krider's argument that the threat of the New York Stock Exchange to move to New Jersey is analogous to a public employee strike. When teachers strike, education cases. If the Stods Excliange moved, citizens of New York would continue to buy and sell stock. New York City might get less tax revenue, to be sure, but it also might get more, depending on what kind of business takes the Exchange's place.

9. Indeed, we suggest that this distortion, as much as anjthing clse, accounts for the socialist planner's aversion to strikes. Such strikes, after all, cannot help but "distort the "plan." 